\title{
STRATEGY OF ENTREPRENEURSHIP EDUCATION BASED ON DIGITAL TECHNOLOGY FOR STUDENTS IN THE WORLD WORKING IN INDONESIA
}

\author{
Sri Rohaetin \\ Faculty of Teacher Training Education, University of Palangka Raya, Indonesia \\ email:rohaetin@edu.upr.ac.id
}

\begin{abstract}
Unemployment and the low multidisciplinary labor market in Indonesia are multidimensional problems that are actually able to be solved. The solution the Indonesian government hopes is that unemployment can fall by increasing the quality of education and entrepreneurship. The purpose of this study is to provide a model of developing strategies that can be done to develop the potential of entrepreneurship education through the implications of digital technology so that the younger generation has the ability to start up and entrepreneurial spirit in the future. By using qualitative analysis sourced from the results of a literature study, researchers found that entrepreneurship education strategies based on local wisdom and assistance in adopting digital technology will be able to reduce unemployment and increase entrepreneurial creativity of the nation's children to compete and face the world of work. But in its development, a good collaboration is needed between support from government policies, teaching staff, and high interest and motivation from students to make it happen.
\end{abstract}

Keyword: education; entrepreneurship; digital technology.

\begin{abstract}
ABSTRAK
Pengangguran dan pasar tenaga kerja multidisiplinyang rendah di Indonesia adalah masalah multidimensi yang sebenarnya dapat diselesaikan. Solusi yang diharapkan pemerintah Indonesia adalah pengangguran dapat turun dengan meningkatkan kualitas pendidikan dan kewirausahaan. Tujuan dari penelitian ini adalah untuk memberikan model pengembangan strategi yang dapat dilakukan untuk mengembangkan potensi pendidikan kewirausahaan melalui implikasi teknologi digital sehingga generasi muda memiliki kemampuan untuk memulai dan semangat kewirausahaan di masa depan. Dengan menggunakan analisis kualitatif yang bersumber dari hasil studi literatur, peneliti menemukan bahwa strategi pendidikan kewirausahaan berdasarkan kearifan lokal dan bantuan dalam mengadopsi teknologi digital akan dapat mengurangi pengangguran dan meningkatkan kreativitas wirausaha anak-anak bangsa untuk bersaing dan menghadapi dunia kerja. Namun dalam perkembangannya, diperlukan kolaborasi yang baik antara dukungan dari kebijakan pemerintah, staf pengajar, dan minat serta motivasi yang tinggi dari siswa untuk mewujudkannya.
\end{abstract}

Kata Kunci: pendidikan; kewirausahaan; teknologi digital. 


\section{INTRODUCTION}

Tight global economic competition, especially technology, economic crisis that is full of uncertainty, labor market potential and high unemployment are some of the factors that influence the important role of entrepreneurship education (Sanchez \& Sahuquillo, 2017). Based on data from the Indonesian Central Statistics Agency, BPS revealed that the number of unemployed people in 2017 was 7.04 million people, until February 2018 this figure had dropped by $5.13 \%$ from $5.33 \%$ or around 140,000 people. The total number of employment figures for 2018 increased by 133.94 million with unemployment reaching 6.87 million and those who had 127.07 million. The highest distribution of unemployment is in the area of West Java at $8.16 \%$, second place in Banten is 7.72\%, and Maluku in the range of 7.38\%. While the lowest percentage was in the island of Bali with $0.86 \%$, West Sulawesi with 2.45\%, and Bengkulu with a percentage of $2.70 \%$. In diagram form as below;
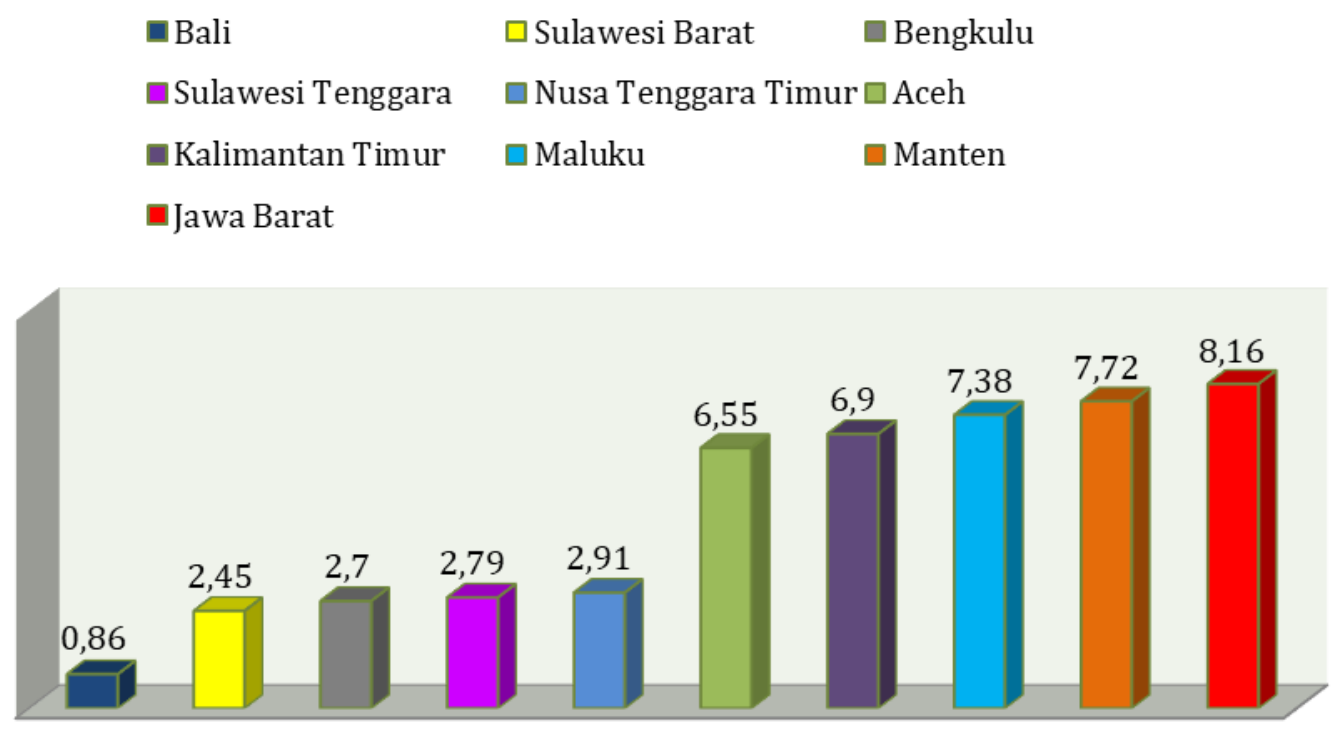

Picture 1. Unemployment Distribution in Indonesia (\%) Source: cnbcindonesia, 2018

From the statistical data table 1 shows the phenomenon of inequality in the level of unemployment in Indonesia. The level of unemployment has decreased statistically, but the number of people who have jobs is still low. The strategic role of entrepreneurship education is one of the solutions to reduce unemployment, where the unemployment rate of Vocational High School graduates contributes the highest number to $8.92 \%$. The high cost of tertiary education, the wrong mindset, and the need to spend large business capital is an obstacle faced by parents of parents and young people.

Entrepreneurship education has so far played a significant role in promoting entrepreneurial intentions and promoting the development of enterprising and hardworking citizens. Education and training can contribute to improving management knowledge and developing psychological attributes and individual behavior (Do Paco, et al., 2015). Individuals who have work skills for tertiary education graduates are more market conscious and creative in job search. They are able to predict which job offers will and will not match their abilities and skills as an entrepreneur. Entrepreneurship education helps individuals to get better jobs (Kucel, et al., 2016)

Based on the historical record of Indonesia's economic crisis in the 90s, it was evident that small, medium and micro businesses (MSMEs) were able to survive. And at this time where conditions of slowing people's economic growth are projected to only experience 
growth reaching 5.3\% impacting the development of SMEs as many as 59.2 million people and who have gone online there are around 3.9 million people while in 2019 those who have gone online are projected will rise 8 million people. MSMEs succeeded in contributing 95\% of the workforce and 64\% of Indonesia's gross domestic product (GDP). Even based on statistical data as of the end of 2018 it reached 14.837 trillion (tribunnews.com, 2019). In addition, the Founder Center for Indonesia Taxation Analysis (CITA) stated that in 2018 tax contributions from the MSME sector reached 6 trillion.

The development of digital economy where the high internet users reached 93.4 million people or increased 40\% from 2018 in the country is one of the factors of the high online use by MSMEs. The value of e-commerce business is predicted to reach USD 130 billion with a growth rate of 50\% per year. In 2020, Indonesia's online business revolution will boost Gross Domestic Product by 22\%. Indonesia's digital economy this year is USD 40 billion or 556.6 trillion. (Kominfo, go.id, 2019)

To realize the face of the digital economy based MSME in 2020, of course, it takes effort to build the soul and potential of entreneurship for UMKM candidates and actors. If SMEs do not master entrepreneurship education including technology and local wisdom, it will be constrained by 1) the slow growth and development of MSMEs which have an impact on the low economic growth of society so that the decline in people's purchasing power; 2) there is a sense of concern and uncertainty in the global economy so as to cause fear in the future halt of life; 3) cause dependence on imported products, loans and foreign investment; and 4) the existence of unfair competition among SMEs. (balipost.com, 2019)

In its development, there was a lot of debate whether then entrepreneurship education is something that is important for today's young generation. Even though entrepreneurship education has been integrated in a new engineering degree, is it enough to enhance entrepreneurship among students? Does entrepreneurship education can really influence entrepreneurial behavior. The purpose of this study is to reveal this issue and provide a review of previous research on what strategies are suitable in entrepreneurship education programs in the technology era 4.0.

\section{LITERATURE REVIEW}

\section{Entrepreneurship Education}

According to Scarborough and Zimmerer (2008) there are eight entrepreneurial values namely; "1) Desire for responsibility, that is a sense of responsibility for the work done; 2) Preference for moderate risk by always avoiding risks that are too high or too low; 3) Confindence in their ability to succeed, convincing themselves that individuals can succeed and succeed; 4) Desire for immediate feedback, always responsive in the face of feedback; 5) High level of energy, having enthusiasm and hard work and perseverance in efforts to realize a better future; 6) Future orientation, having views and insights far ahead; 7) Skill at organizing, having skills in allocating resources to create productive added value; and 8) Value of achievement over money, more respect for achievement and hard work compared to the money generated."

Some programs carried out by the government in relation to entrepreneurial values appear to have not been maximized. To create a productive society that has important values like this will certainly require a lot of hard work from all parties. It can't be only a handful of organizations or people who are distressed. Entrepreneurship program is one step to reduce unemployment. In other words, the empowerment of human resources who are able to practice entrepreneurial values is very important.

"As for the characteristics of entrepreneurship, an entrepreneur will have a positive character, among others; 1) Confidence confident, optimistic, able to commit 
well, be disciplined and responsible for their work; 2) have a high initiative so that individuals become energetic, active, and agile in acting; 3) has achievement motives oriented towards results obtained both now and in the future; 4) have an individual leadership spirit that can be trusted and resilient in overcoming the situation and the environment; 5) Dare to take action in taking risks with full business challenges; and 6) have originality including having adequate references and not taking plagiarism." (Alma, 2010).

Nowadays, entrepreneurial characteristics become something that is very much needed. Without this it will be very far to realize the distribution of wealth. Creating an environment for a conducive world of entrepreneurship is not easy. However, if a positive character can be possessed by every individual/entrepreneur then it is not something that is impossible. This is a discourse towards digital entrepreneurship to create innovation and reach job opportunities and the global industrial job market (Prodanov, 2018; Sarkar, \& Oberoi, 2018; Chepurenko, 2017).

Entrepreneurs are individuals who are able to create a new business by facing risks and uncertainties through identifying opportunities through a combination of available resources and being able to carry out their entrepreneurial activities (Zimmerer \& Scarborough, 2008). Thus it is very clear that entrepreneurship is an important aspect in developing sustainability.

\section{Theory of Planned Behavior (TPB)}

Individual behavior theory in entrepreneurship will be influenced by three factors, namely attitude toward the behavior, subjective norms, and perceived behavioral control (Tung, 2011). The following is a model of entrepreneurial behavior theory.

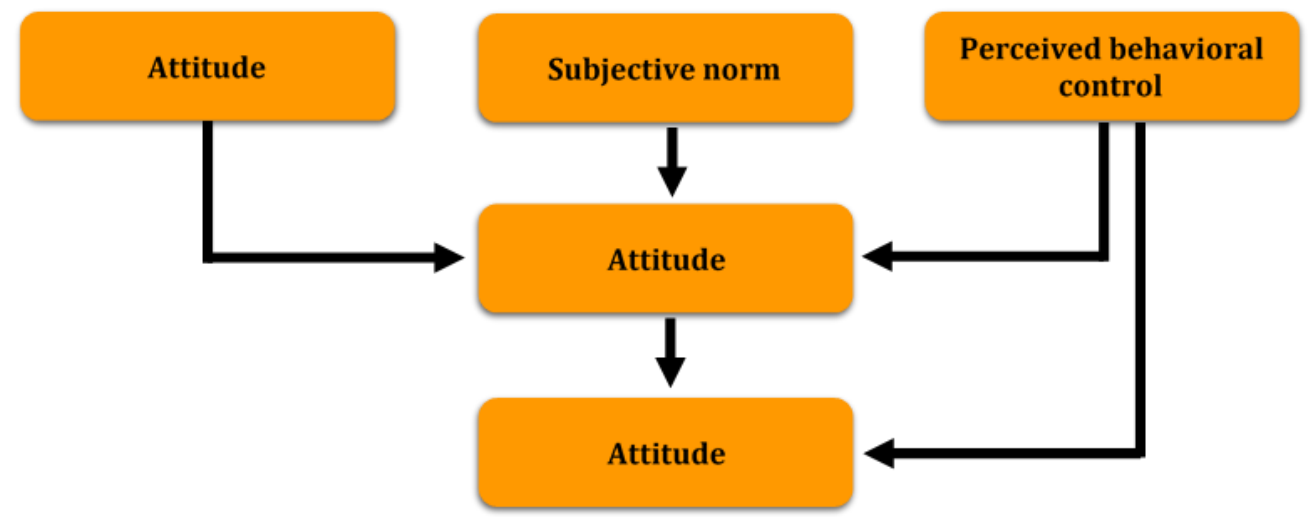

Picture 2. Model Theory of Planned Behavior

Based on Figure 1, it can be explained that attitude stimulates positive responses in individuals. Attitude is a tendency that individuals learn with the aim of responding to an object consistently in both pleasure and displeasure (Assael, 1984). Lo Choi Tung (2011) explains that, "Attitude toward behavior is the degree to which a person has a favorable or unfavorable evaluation of a behavior. It depends on the person's assessment of the expected outcomes of the behavior."

"Subjective Norm refers to social pressures perceived bi individuals to perform the behavior. It relates to the beliefs that other people encourage or discourage to carry a behavior. "(Lo Choi Tung, 2011). Individual views about the mindset of other individuals who are able to support or not support something that refers to social pressure. Meanwhile, Perceived Behavioral Control as an individual's perception of the existence of indications of factors that facilitate or complicate something that is achieved by the individual (Wijaya, 2007). "Perceived Behavioral Control relates to the beliefs 
about the availability of resources and resources or barries to perform an entrepreneurial behavior (control beliefs)." (Lo Choi Tung, 2011)

There are still many unemployment, one of which is a result of human resources that are less able to compete. This is because of the low attitude and entrepreneurial spirit. Good individual behavior is needed as a foundation stone for an entrepreneur to support the achievement of the goals and independence of the nation. It takes inculcation of entrepreneurial values for the behavior of young people who are the main assets of a government. Although it cannot be realized in a short time, karen requires integration at the educational level where noble character education is the most important. So that later, creating a new business can bring prosperity to the community not only to a handful of people.

\section{Basic Concepts of Digital Economy}

Entrepreneurship acts as a catalyst in the pace of technological change. The digital revolution is changing the way entrepreneurs get things done that deliver more effective benefits and significantly more cost and quality efficiency (Sarkar, \& Oberoi, 2018; Prodanov, 2018). This makes it possible to create new jobs with low production costs. The digital economy will encourage investment globally and bring up various skills through digital literacy (Ahmad, Saputro, \& Handayani, 2016; Fauziah, 2019).

Tapscott (1998) explains that, "Digital economy is a sociopolitical and economic system that has the characteristics of an intelligence space that includes information, various access to information instruments and information processing and communication capacity. The components of the digital economy that were successfully identified were the ICT industry, e-commerce activities between companies and individuals, digital distribution of goods/services, sales support for goods/services using the internet system."

Digital economy is a combination of several technologies consisting of general purpose technologies (GPTs) with various forms of economic and social activities carried out by the public through the internet. This includes physical infrastructure based on broadband lines and routers, Google and salesforce devices and IoT applications, data analysis, and cloud computing, and the effective use of Information and Communication Technology (ICT) and information networks (modern information networks) (Report G20 China, 2016). The new fundamental in digital economy consists of information transactions, financial transactions and goods transactions (BPPS Kominfo, 2019)

"Digital economy can be seen as a way to ensure that technological innovation has a minimum risk and is able to produce the maximum benefit. Digital economic development cannot be separated from the influence of technology. In the end, the digital economy can support economic growth, increase competitiveness and productivity, and be able to realize economic and trade cooperation that can be mutually beneficial in the long run. In addition, the digital economy can be utilized by all levels of society. "(Kemenkeu.go.id, 2018).

In its development, new digital is influenced by five components, namely knowledge-based work, globalization, economic dynamism, digital economic transformation, and the capacity of technological innovation (Kauffman \& ITIF, 2007). In its implementation, the digital economy faces many challenges, especially the problem of absorbing skilled and skilled workers. Business development and digital market development have not significantly demonstrated a strong influence on welfare. However, e-entrepreneurship has significantly contributed to the growth of the national economy. (Fauziati, Harahap, \& Novianti, 2018). 


\section{METHOD}

The method used in this research is literature study by studying various references and previous research that is similar to obtain an appropriate theoretical basis on the author's malsaah. (Sarwono, 2006) Relevant information based on social situations in the community aims to get the object of research to get problem solving and avoiding various significant obstacles. (Sugiyono, 2012) This research ultimately wants to obtain a model that can be developed for the development of entrepreneurship education, especially in colleges and universities. This is because, the potential to develop self-forgiveness and creativity can be done by developing a good entrepreneurial spirit that is in accordance with the times and market demand.

\section{RESULT AND DISCUSSION}

Rapid technological advancements require the world of entrepreneurship education to innovate to create new strategies in capturing the potential of the world economy. Efforts to accelerate by abandoning traditional ways and then oriented towards entrepreneurial practices in the digital age. Although in practice there will be many obstacles, it does not mean that it is not possible to create opportunities to reduce unemployment and multiply multidisciplinary employment by creating multidimensional digital-based entrepreneurship education in the future, seeing the swift flow of economic competition around the world.

Theoretically, entrepreneurship basic education will form a general competency that supports the various skills needed by entrepreneurs to succeed in business (Kolstad \& Wiig, 2015). A research study on entrepreneurship education reveals the important implications of practical entrepreneurial practices. Higher self-efficacy is associated with lower entrepreneurial intentions of students in theoretical education compared to practical orientation (Piporopoulus \& Dimov, 2015; Rauch \& Hulsink, 2015; Maresh, et al., 2016). Entrepreneurial intentions can be naturally driven by the need for student self-sufficiency (Sanchez \& Sahuquillo, 2018).

The entrepreneurship education program really influences the attitudes and intentions of students in building the attitudes and mentality of an entrepreneur (Fayolle \& Gaily, 2015; Karimi, et al., 2016). Business interest is not brought from birth, but can grow and develop from self and the environment including education and training and then the growth of individual decisions to entrepreneurship (Bygrave, 2003) Therefore, so students can improve their lives through entrepreneurship education later, students must increased entrepreneurial interest. There are four things that affect entrepreneurial decisions including individual personal, cultural environment, social conditions, and a combination of these three factors (Lambing \& Kuehl, 2007). Whereas Alma (2010) added factors of the educational environment, individual personality and family environment.

Entrepreneurship education must be action based. This is done to create innovation through the creation of new businesses and new business areas. The fact of limiting the availability of competent human resources becomes an obstacle for the company to become a potential for students later. Universities / Colleges can overcome this need by increasing the motivation and competence of graduates to become resources needed by companies or businesses in innovative and entrepreneurial activities. Entrepreneurship education has traditionally focused on individual teaching, but there are not many initiatives that have an orientation to entrepreneurial actions or practices (Rasmussen, 2006;). In addition, identifying business opportunities, developing business strategies, and allocating resources are one of the key elements that must be prioritized in entrepreneurship education programs (Knight, 1987). 
Strategies using innovative management in business, including market analysis and planning, determining prices, financial strategies, leadership abilities, and human resources as well as knowledge and skills in building various management dimensions (Block \& Stumpf, 1992). The scope of entrepreneurship education must be included in various aspects of business management and other fields which in turn will encourage the emergence of new business start-ups. The ability to analyze all forms of obstacles and solutions to overcome them must also be instilled in students. (Ronstadt, 1990).

Various skill provisions include leadership skills, the ability to communicate and develop products (Plumly et al., 2008), as well as innovations in communication and information technology. (Richardson \& Hynes, 2008) Other studies explain that the focus is on introducing entrepreneurship as an alternative career (Hills \& Leitch, 2017) by centering around venture capital sources (Vesper \& McMullan, 1988) by exploring existing business opportunities (Zahra \& Dess, 2001; Solomon et al, 2002). Developing entrepreneurship education can be done by prioritizing improvement strategies in four main aspects namely; “1) Including content (e.g., finance / cash management, engineering \& accounting); 2) Skills (leadership, communication, and human relations) and behavior; 3) Mentality (e.g., creativity and supportive thinking); and 4) Personality (e.g., self-motivation and risktaking)."(Hood \& Young, 1993).

Based on previous research findings, a model of development of entrepreneurship education can be developed using digital technology as follows;

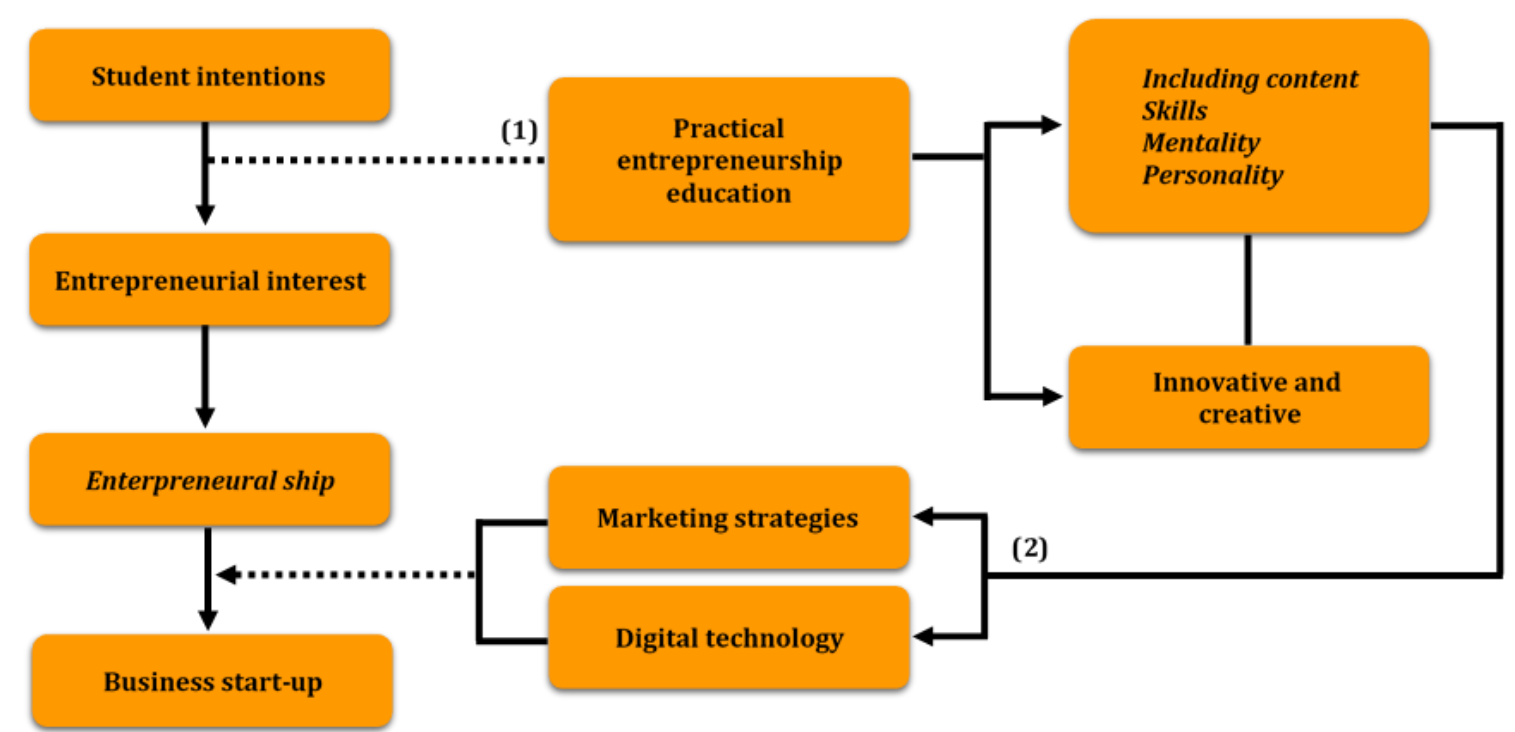

Picture 3. The development model of the Theory of Entrepreneurship Education uses Digital technology

1) Entrepreneurial intentions can be grown from entrepreneurship education so as to generate interest in entrepreneurship. Various aspects and dimensions that can be done in the practical process. 2) the emergence of creativity and innovation can shape the character of students who are able to make management strategies that are good enough to learn to develop their entrepreneurial spirit. Digital technology will help to realize business start-ups that are in accordance with the times and the needs of today's generation of digital era. Good entrepreneurship learning by implementing digital technology involves four sets of activities: 1) applying entrepreneurial ideas for engineering; 2) understand the problem of entrepreneurship in a new way that is using digital technology; 3) personal development 
oriented to creative and innovative actions; and 4) manifesting themselves through collective efforts.

Meanwhile, to evaluate and feedback on the effectiveness of learning can use fourdimensional indicators of variation consisting of the nature of learning, responses to pedagogy, relationships with work teams, and learning outcomes (Taks \& Kukemelk, 2016). These four indicators are commonly used criteria to measure the effectiveness of a learning. By measuring the effectiveness and accuracy of the entrepreneurship learning program, it is hoped that the next program will be more effective. This is done as an accelerator of developing the digital economy for entrepreneurship. Without the right indicators, one cannot judge whether the programs that have been carried out are actually running effectively or even vice versa. The four sets of activities that have been described are intended as a series of whole and inseparable. The results of the study offer a good model of entrepreneurial learning. In other words, several learning alternatives must be carried out mainly because the development of digital technology will continue to evolve so that continuous strategy adjustments are needed.

In addition, early actions taken in entrepreneurship education using digital technology must look at the prospects of digital economy among other things; 1) content management and design adjustments used; 2) the comfort of paying for consumers; 3) correct data processing; and 4) conquering mobile devices. (BPPS Kominfo, 2019).

Please note that, early action can be done from the beginning within the scope of the nuclear family. In fact, learning that is captured in the nuclear family environment will greatly influence individual behavior early on. True environment will shape individual characteristics. Likewise entrepreneurship education using digital technology implemented in the socioeconomic environment is in dire need of government support. Without this support, even though the high prospects of the digital economy will not be maximized in achieving national goals. Digital economy without the characteristics of good entrepreneurial behavior will not create a digital economy that can achieve prosperity. Here, the role of learning entrepreneurship education is a way to overcome the problem of unemployment.

The availability of practical entrepreneurship education tends to foster an attitude of vigilance and foster risk-taking skills (Westhead \& Solestivik, 2016). Students will learn how to find solutions to face various obstacles and create innovation when facing real business challenges. For example by providing an innovative teaching program called 'Learning to be', which focuses on developing entrepreneurial attitudes and skills using digital technology through project-based learning methodologies inspired in The Design Thinking process (Daniel et al., 2016). The development of entrepreneurship education by utilizing digital technology in entrepreneurial practices can be done for example by using e-commerce. Students can be taught using various forms of new media and the ability of how to predict consumer tastes, the environment, and the needs of millennial generations and then create a variety of product innovations such as halal products or environmentally friendly products of course by creating good quality products at low cost, easy and effective (Utami \& Asriani, 2019) Thus, the potential for quality human resources can be formed through practical training and independent entrepreneurial intentions of the students themselves.

\section{CONCLUTION}

The development of entrepreneurship education is very important to develop the potential of students so they have the skills that are appropriate to the needs of the company and the current economy. By using based on local wisdom and technology adoption assistance, students will be more familiar with the development of the era in the era of 
digitalization so as to create new innovations in learning new business opportunities. Entrepreneurship education by means of technology can encourage students' interest to continue to learn to explore their potential so that later they can compete in the global industry, of course the role of the environment and students as well as government regulations in terms of a better educational curriculum is needed to support the generation of entrepreneurial students.

\section{REFERENCES}

Achmad, N., Saputro, E. P., \& Handayani, S. (2016). Entrepreneurship in the Digital Era. Educational Dynamics, 11 (2), 102-107.

Alma, Buchari. (2010). Entrepreneurship for Students and the Public. Bandung: Alfabeta.

Assael, H. (1984). Consumer behavior and market action. Boston, MA: Kent.

Balipost.com. (2019) The face of MSME in 2019. (18 januari 2019, 15:56 WIB). URL: http://www.balipost.com/news/2019/01/18/66391/Wajah-UMKM-pada-Tahun2019.html

Barba-Sánchez, V., \& Atienza-Sahuquillo, C. (2018). Entrepreneurial intention among engineering students: The role of entrepreneurship education. European Research on Management and Business Economics, 24(1), 53-61.

Badan Penelitian dan Pengembangan SDM (BPPS) Kominfo. (2019). Study of the Digital Economy in Indonesia as the Main Driver of the Future of Digital Formation.URL: https://balitbangsdm.kominfo.go.id/?mod=publikasi\&a=dl\&page_id=222\&cid=29\& download_id=149

Brown, d. \& Brooks, L. (1991). Career Counseling Techniques. Boston: Allyn \& Bacon.

Bygrave, W. D. (2003). The Portable MBA Entrepreneurship. Jakarta: Binarupa Aksara.

Chepurenko, A. (2017). Innovation Entrepreneurship in Transition Economies: Problems and Outlook. Форсайт, 11 (3 (eng)).

Purnomo, Herdaru. 2018. Which region is the highest unemployment rate. (8 may 2018, 16:40).

cnbcindonesia.com.

URL:https://www.cnbcindonesia.com/market/20180508163742-20-14147/didaerah-mana-tingkat-pengangguran-terbanyak-di-indonesia

Daniel, A. D., Costa, R. A., Pita, M., \& Costa, C. (2017). Tourism Education: What about entrepreneurial skills?. Journal of Hospitality and Tourism Management, 30, 65-72.

Do Paço, A., Ferreira, J. M., Raposo, M., Rodrigues, R. G., \& Dinis, A. (2015). Entrepreneurial intentions: is education enough?. International Entrepreneurship and Management Journal, 11(1), 57-75.

Fauziati, P., Harahap, E. F., \& Novianti, N. (2018). Factors Affecting The Digital Development of The Economy in Western Sumatra. Asia Proceedings of Social Sciences, 2 (2), 2125.

Fauziah, M., Wulandari, S. Z., \& Afif, N. C. (2019). Empirical Study of Intention to Redeem Mobile Coupons; Evidence of the Influence of Socializing, Economic Benefits, and Trust Variables. ICORE, 5 (1).

Fayolle, A., \& Gailly, B. (2015). The impact of entrepreneurship education on entrepreneurial attitudes and intention: Hysteresis and persistence.Journal of small business management, 53(1), 75-93.

Henry, C., Hill, F., \& Leitch, C. (2017). Entrepreneurship Education and Training: The Issue of Effectiveness: The Issue of Effectiveness. Routledge.

Hood, J.N \& Young, J.E. (1993). Enterpreneurship's Requisite Areas Of Development: A Survey Of Top Executives In Succesful Entrepreneurial Firmas. Journal of Business Venturing 8(2): pp. 115-135. 
Karimi, S., Biemans, H. J., Lans, T., Chizari, M., \& Mulder, M. (2016). The impact of entrepreneurship education: A study of Iranian students' entrepreneurial intentions and opportunity identification. Journal of Small Business Management, 54(1), 187209.

Kauffman \& ITIF. (2007). The 2007 State New Economy Index: Benchmarking Economic Transformation In The States. URL: https://www.itif.org/files/2007_State_New_Economy_Index_Small.pdf

Kucel, A., Róbert, P., Buil, M., \& Masferrer, N. (2016). Entrepreneurial Skills and EducationJob Matching of Higher Education Graduates. European Journal of Education, 51(1), 73-89.

Kemenkeu.go.id. (2018). Growing Rapidly, Need a Strategy to Face the Digital Economy. URL: https://www.kemenkeu.go.id/publikasi/artikel-dan-opini/tumbuh-pesat-perlustrategi-hadapi-ekonomi-digital/

Kominfo.go.id. (2019). Indonesia will be the Largest Digital Economy Player in Southeast Asia.URL:

https://kominfo.go.id/index.php/content/detail/6441/Indonesia\%2BAkan\%2BJadi \%2BPemain\%2BEkonomi\%2BDigital\%2BTerbesar\%2Bdi\%2BAsia\%2BTenggara/0 /berita_satker

Kolstad, I., \& Wiig, A. (2015). Education and entrepreneurial success. Small Business Economics, 44(4), 783-796.

Lambing, P. \& Kuehl, C. R. (2007) Entrepreneurship 4th edition. Upper Saddle River: Prentice Hall.

Maresch, D., Harms, R., Kailer, N., \& Wimmer-Wurm, B. (2016). The impact of entrepreneurship education on the entrepreneurial intention of students in science and engineering versus business studies university programs. Technological forecasting and social change, 104, 172-179.

Piperopoulos, P., \& Dimov, D. (2015). Burst bubbles or build steam? Entrepreneurship education, entrepreneurial self-efficacy, and entrepreneurial intentions. Journal of Small Business Management, 53(4), 970-985.

Prodanov, H. (2018). Social Entrepreneurship And Digital Technologies. Economic Alternatives, 1 (1), 123-138.

Rauch, A., \& Hulsink, W. (2015). Putting entrepreneurship education where the intention to act lies: An investigation into the impact of entrepreneurship education on entrepreneurial behavior. Academy of management learning \& education, 14(2), 187204.

Rasmussen, E. A., \& Sørheim, R. (2006). Action-based entrepreneurship education. Technovation, 26(2), 185-194.

Ronstadt, R. (1990). The educated entrepreneurs: A new era of entrepreneurial education is beginning. In C. A. Kent (Ed.), Entrepreneurship Education (pp. 69-88). New York: Quorum Books.

Sarwono, J. (2006). Quantitative and Qualitative Research Methods. Yogyakarta: Graha Ilmu.

Sarkar, M. P., \& Oberoi, S. (2018). Digital entrepreneurship and its effect on employment opportunities and labor market in India: A review. International Journal of Management, IT and Engineering, 8 (3), 248-261.

Sugiyono. (2012). Quantitative research methods and R\&D. Bandung: Alfabeta.

Tapscott, D. (1998) Digital Economy: Promise and Peril in the Age of Networked Intelligence. New York: McCraw-Hill. 
Täks, M., Tynjälä, P., \& Kukemelk, H. (2016). Engineering students' conceptions of entrepreneurial learning as part of their education. European Journal of Engineering Education, 41(1), 53-69.

Tribunnews.com. (2019). Assistance for Adoption of Key Technology of UMKM Grades Up. (4 november 2019, 14:07 WIB). https://www.tribunnews.com/techno/2019/11/04/pendampingan-adopsiteknologi-kunci-umkm-naik-kelas

Tung, L. C. (2011). The impact of entrepreneurship education on entrepreneurial intention of engineering students. City University of Hongkong: Run Run Shaw Library.

Utami, P. (2019). Optimization of utilization of E-commerce on halal products in Indonesia. Eastern Jornal of Economics and Finance, 4(1), 14-23.

Wahyuno, Budi. (2013) The Effect of Entrepreneurship Education on Entrepreneurship Intention of State Vocational School Students 1 Medan Tahun 2013. Tesis PPs UNS.

Westhead, P., \& Solesvik, M. Z. (2016). Entrepreneurship education and entrepreneurial intention: do female students benefit?. International Small Business Journal, 34(8), 979-1003.

Zimmerer, Thomas W. \& Scarborough. (2008). Entrepreneurship and Small Business Management. Jakarta: Salemba Empat 